\title{
The problem of fear in TQM - causes, consequences and reduction methods - a literature review
}

\author{
Marek Bugdol \\ Department of Economics and Management, Uniwersytet Jagielloński, \\ Kraków, Poland
}

\begin{abstract}
Purpose - The primary objective of the paper is to present the role and meaning of fear in organizations implementing TQM. The author's intention is to identify the causes of fear in the TQM components as well as the main types of fear, their causes, consequences and methods of reduction.

Design/methodology/approach - The main research method applied is a systematic review of the literature on the subject. The applied systematic review procedure takes into consideration the indicated research objective, the selection of the basic literature and publications, the presentation of the publication database and content analysis. The author also makes use of his own observations ensuing from his acting in the capacity of a TQM consultant and a juror of the Polish Quality Award.

Findings - The paper presents the causes of fear in the TQM components, the main types of fear and its consequences. The limited possibilities of eliminating fear are also indicated. Fear appears when, for various reasons, TQM is improperly implemented and maintained, but also when resources are allocated incorrectly (e.g. a wrong selection of quality team members), and it is included in social processes (e.g. in the quality team forming process). It appears when only structural empowerment rather than mental empowerment is applied, when there exist contradictory expectations with regard to empowerment, in case of excessive and/or "have to" commitment in particular employees, and when too much emphasis is placed on commitment.

Research limitations/implications - The reflections included in the paper may become useful for quality management practitioners, as such knowledge allows them to avoid mistakes which are the cause of fear, that is an emotion making quality improvement difficult. The paper does not present the manifestations and sources of fear in all TQM components, and they are certainly included in a broadly understood quality culture. Nevertheless, the gathered and arranged knowledge can be the source of further research.

Originality/value - Being the result of the studies of the literature on the subject, this paper is one of few publications discussing in a detailed manner one of the principles of effective quality management formulated by E. Deming, namely "driving fear out".
\end{abstract}

Keywords Fear, Empowerment, Commitment, Quality team, Leadership

Paper type Conceptual paper

\section{Introduction}

Fear is one of the fundamental emotions, a process combining four elements: physiological arousal, subjective feelings, cognitive interpretation and behavioral expression (Zimbardo et al., 2017, p. 44). The notion of fear is related to terms such as apprehension, uncertainty, risk, anxiety, horror. The terms fear and anxiety are often used interchangeably but "anxiety is seldom clearly represented, as such, in awareness, whereas fear is often unequivocal" (Schulz, 2006, p. 111). Thus the notion of fear is different from the notion of neurotic anxiety.

(C) Marek Bugdol. Published by Emerald Publishing Limited. This article is published under the Creative Commons Attribution (CC BY 4.0) licence. Anyone may reproduce, distribute, translate and create derivative works of this article (for both commercial \& non-commercial purposes), subject to full attribution to the original publication and authors. The full terms of this licence may be seen at http:// creativecommons.org/licences/by/4.0/legalcode
Received 7 February 2019

Revised 6 May 2019

23 July 2019

29 September 2019

25 November 2019

Accepted 13 January 2020 
TQM

32,6

Fear appears when people face external risks. Describing causes of fear, E. Deming also indicates external causes, for example those connected with the appearance of wrong data (Deming, 2012).

The problem of fear is not commonplace in the literature on quality management. It is quite astonishing, since one of the effective quality management principles is that of "driving out fear". The discussion on the role and meaning of fear in TQM was started by E. Deming (1986). In the subsequent years, many other researchers (e.g. Gitlow, 1994; Tamimi and Gershon, 1995; Sadikoglu, 2005) referred to his views on fear. Deming claimed that all quotas, standards, numerical goals and management objectives are opposite to constant improvement, hinder cooperation and cause fear (Deming, 1986). He was convinced that problem solving and employees' commitment could not take place in an atmosphere of fear and no support. In the past, quality control was related to fear because it consisted in controlling employees rather than processes. It was connected with sanctions. Deming, who stressed cooperation, employee commitment and fear reduction, changed the approach to management (Gitlow, 1994). His views were criticized mainly by the supporters of management oriented towards fast achievement of quantitative goals (e.g. Bailey, 1997). They were not confirmed in employee opinion surveys conducted by Sadikoglu (2005).

The TQM philosophy emphasizes the commitment of the top management, the use of statistical techniques of quality control, the improvement in the quality of work environment through education and training, fear reduction and the elimination of numerical quotas (Tamimi and Gershon, 1995). TQM aims at employee empowerment and requires overcoming organizational, communication and interpersonal barriers. However, many TQM implementation programs fail because of the lack of commitment on the part of top management, the fear of changes, the fear of losing power in an organization or a sense of uncertainty (Stabler, 1995; Kolodny, 1995; Waller and Ahire, 1996; Jacokes, 1996). Fear makes it impossible to take up any improvement measures, hinders communication processes and paralyses decision makers.

Fear plays an important role in TQM. Therefore, it deserves to be researched carefully. Consequently, the primary objective of the paper was to present the role and meaning of fear in organizations implementing TQM. The author's intention was to identify the causes of fear in the TQM components, its main types, consequences and reduction methods.

The current status of research on the subject as reflected in the TQM literature This section presents an outline of the issue of fear as addressed in publications on TQM. The conducted analysis of the literature concerning the problem of fear in TQM allowed the author to distinguish several thematic areas.

The first thematic area concerns the general causes of the fear of changes. It refers in particular to E. Deming's views on the causes of fear (Deming, 1986; Sadikoglu, 2005), the fear of changes (Stabler, 1995; Kolodny, 1995), the fear of losing power in an organization (Waller and Ahire, 1996), a lack of support and situations of uncertainty (e.g. Jacokes, 1996).

Deming claimed that all quotas, standards, numerical goals and management by objectives were counter to constant improvement, undermined cooperation and teamwork in a company and caused fear (Deming, 1986). Empirical research proves, however, that timebased standards do not have to increase fear and distrust (Sadikoglu, 2005).

The literature on the subject shows that in the initial stage of TQM implementation people are afraid of changes (e.g. Stabler, 1995). Fear increases when they perform tasks in a new work environment (Kolodny, 1995). One factor making the implementation of TQM difficult is the fear of losing one's position, power or perhaps even employment (Waller and Ahire, 1996). The implementation of TQM and many other management concepts such as re-engineering or knowledge management generates a sense of threat and fear (Gordon, 1995; Pastore, 2003). 
In the course of implementing all changes oriented towards the improvement of productivity, attention is paid to not only organizational transformations, but mainly the necessity of changing the organizational culture and eliminating fear or anxiety connected with the change process (Carmody, 1994). The fear of changes is not only caused by apprehension of novelty and the unknown but also results from uncertainty and a lack of support from management (Jacokes, 1996; The antidote to fear-driven management, 2012).

The second thematic area focuses on deliberations concerning the two opposite concepts: Drive in Fear and Drive out Fear (e.g. Repenning, 2000; Wicks, 2001). These deliberations are connected with providing an answer to the following question: What is the role of fear in quality improvement and does it play a negative role only?

Undoubtedly, the implementation of Total Quality Management or any other new management concept causes fear which can be more intense if the scope and impact of changes is large enough. The literature presents two opposite theories concerning the influence of work safety on the ability of companies to implement changes. According to the "Drive out Fear" principle, organizations need to participate in ensuring work safety, while the "Drive in Fear" principle emphasizes the positive role played by uncertainty in justifying changes (Repenning, 2000). Some researchers and management consultants stress the positive role played by the fear of losing employment in motivating people to implement changes. For instance, Kotter (1995) discusses cases in which managers deliberately highlight poor business results, and the probability of future losses motivates people to implement changes and improvement processes. Bailey (1997) also claims that the fear of losing employment is a valuable ally for managers intending to implement a serious organizational transformation. Such views are contrary to TQM ideas, however, because, first of all, they refer to financial results only and disregard social results. Secondly, they put emphasis on motivation oriented towards short-term objectives, which was rejected by Deming. Fear may force organizations to take up pro-quality activities. Referring to organizations implementing quality management systems and TQM, Naveh et al. (2004) use the terms "first and second movers". "First movers implement a new management practice because of real needs and a high fit between what the practice suggests and their needs (technical efficiency), second movers implement the new management practice because of customer pressure and the fear of falling behind the competition (external pressure)" (Naveh et al., 2004, p. 1843). Conducting benchmarking analyses may also be caused by the fear of losing the ability to compete with others (Panwar et al., 2013). The role of fear, in particular the fear of death, is used in various programs aimed at improving work safety, and even in "zero defects" programs (Halal and Lasken, 1980).

The third thematic area focuses on the consequences of fear (Craig and Lemon, 2008, Bloom et al., 2015; Bugdol and Bortniczuk, 2018). In organizations dominated by a culture of fear, where employees are punished, the acquisition of information of the true causes of failures in quality improvement is very difficult (Craig and Lemon, 2008). Not only efficiency but also quality suffers on account of fear. Employees of many companies do not suggest any corrective measures in fear of punishment. Consequently, such companies have no opportunity to improve quality, and top-down initiatives bring no results (Bugdol and Bortniczuk, 2018). Researchers agree that higher competition results in higher management quality. Yet, when fear dominates, decision-making processes are considerably more difficult (cf. Bloom et al., 2015).

Previous publications described the notion of fear and its role in quality management in a rather general manner. They claimed that fear should be eliminated as its presence hindered quality improvement.

But they failed to describe fear in the particular components of TQM such as commitment, leadership, empowerment or teamwork. Identifying the types of fear, their causes as well as consequences not only in the general TQM principles but also in the particular components of
A review of problem of fear in TQM

1219 
TQM

32,6

1220

TQM (e.g. leadership, commitment, empowerment, teamwork) is important both for the theory as well as the practice of quality management. Commitment was found to be one of the TQM principles and its role was described in many works (e.g. Oakland, 1995; Arunachalam and Palanichamy, 2017; Soltani et al., 2005). Leadership plays a special role in TQM, which has been proved in many researches (e.g. Oakland, 1995; Roberts, 2004; Calvo-Mora et al., 2005; Calvo-Mora et al., 2018). Empowerment plays an equally significant role (Randeniya et al., 1995; Zink, 1995; Jayaram et al., 2010; Youssef, 2010). Many authors emphasize the importance of teams, particularly quality circles, in both the implementation and the maintenance of TQM (Brockner and Hess, 1986; Oakland, 1995; Jajoo and Kakkad, 2016). Obviously, various publications mentioned many other components of TQM such as teamwork, leadership, pursuing lower costs of quality, following the process-based approach, using statistical methods, satisfaction of internal and external customers, influence on the environment, self-assessment, resources management, quality policy and quality strategy. They can be divided into hard and soft elements. Nevertheless, even the four selected elements can constitute a sufficient basis for identifying the sources and consequences of fear in TQM. Various publications present evidence indicating that fear plays a significant role in these particular components (e.g.: Goldstein, 1985; Stoner et al., 2001; Bragg, 2002; Greasley et al., 2005; Babalola et al., 2016; Andrade et al., 2017 ; Guo et al., 2018; Bugdol and Bortniczuk, 2018; Kopányi-Peuker et al., 2018).

There is also a lack of publications focusing on the types, causes and consequences of fear that can be distinguished within the TQM concept. The literature not related to TQM also distinguishes various types of fear. For example the fear of changes (Stabler, 1995; Kolodny, 1995; Soltani et al., 2005), the fear of losing power in an organization (Walle and Ahire, 1996), the fear spreading to employees due to improper management styles (cf. Babalola et al., 2016; Guo et al., 2018), the fear of other people (Grenny, 2015), the fear of exclusion (Kopányi-Peuker et al., 2018). Taking into consideration the unique character of TQM and its components indicated above, it can be assumed that there exist types of fear that can be attributed to each of them. This means that, for instance, the fear of exclusion may be experienced by people strongly attached to their work teams, and the fear spreading to employees due to improper management styles results from inappropriate leadership, etc. There is also a shortage of publications showing how fear can be alleviated and conquered in TQM.

The methods of reducing the fear of changes are described most extensively (Stabler, 1995; Kolodny, 1995; Soltani et al., 2005; Weeks et al., 2004; Dziadkiewicz and Juchniewicz, 2013; Morris, 2015), but there is not enough knowledge of how to address other types of fear related to TQM.

Taking into consideration the identified publication gap, the following questions can be posed:

(1) What types of fear can be distinguished within the TQM concept?

(2) What are the causes of fear?

(3) What consequences of fear can be distinguished within the TQM concept?

(4) What are the possibilities for reducing the particular types of fear?

Types of fear

Based on previous literature studies, the following types of fear can be listed::

(1) the fear of changes (Stabler, 1995; Kolodny, 1995; Soltani et al., 2005),

(2) the fear of assessment and of failure to achieve planned results (Deming, 1986),

(3) the fear of losing power in an organization (Walle and Ahire, 1996), 
(4) the fear experienced by employees due to improper management styles (Nwabueze, 2011; Babalola et al., 2016; Guo et al., 2018; Bugdol; Bortniczuk, 2018),

(5) the fear of punishment (Drummond, 1998; Tremblay et al., 2013; Bugdol, 2018a),

(6) the fear of others (Grenny, 2015),

(7) the fear of exclusion (Kopányi-Peuker et al., 2018).

The fear of change is associated with the fear of losing power in an organization, a lack of support, and situations of uncertainty. Usually these types of fear are noticeable at the beginning of implementing various management concepts - not just TQM. These types of fear are best described in the literature. The fear experienced by employees due to improper management styles appears at various stages of the implementation, maintenance and improvement of the TQM concept. It is associated with the fear of punishment that both employees and managers can feel (even CEOs may be afraid of shareholders, owner). Further types of fear, that is fear from others and of exclusion, are also interrelated and result from the presence of other people in the organization. Due to the fact that TQM uses different forms of teamwork, it could be thought that this kind of fear is also character-specific for TQM, but actually, it can occur in any other organization.

The literature so far does not indicate which sources and consequences of fear we are dealing with in the components of TQM, and therefore an attempt was made to answer this question in the next part of the article.

\section{Fear in selected components of TQM}

This section discusses probable causes of fear connected with the four selected components of TQM, i.e. commitment, leadership, empowerment, and teamwork. The selection of these particular components is justified in the description below. The paper uses some basic definitions of TQM (e.g. Oakland, 1995). In his research, the author refers to the classical approach to TQM, especially the views of E. Deming (mainly the idea of the deadly diseases in organizations), and the concepts aimed at distinguishing the particular components of TQM.

\section{Commitment}

Fear is presented the most often as the cause of a lack of commitment (Tsai and Young, 2010), and rightly so, but the perverse question could be asked whether commitment itself triggers fear.

Researchers agree that commitment is one of the most important principles of TQM (Arunachalam and Palanichamy, 2017). Its absence is said to be the cause of failure of TQM program implementation. The commitment of top management is particularly significant because connections among the commitment of top managers and employees, as well as the effectiveness of TQM programs are usually very close and linear (Soltani et al., 2005).

However, in order to diagnose the problem of commitment properly, one should pay attention to not only the existence of linear relations (even though they are very important). It is worth mentioning that there are many types of commitment, which is not taken into account in many researches. The following authors introduced their own typologies of commitment: Mayer and Schoorman (1998, p. 15), Witt et al. (2001), Bragg (2002), as well as many others. The most frequently mentioned types of commitment include: effective and continuing, "to be found in an organization", organizational, related to work, profession, or supervision, "have to", "want to" or "should", effective and normative, calculative and behavioral. A review of these typologies shows that, in TQM, value-based commitment (e.g. 
TQM 32,6 commitment based on trust, justice) and ideological commitment (occurring when someone works for an idea, value system, primary objective) should be dominant. This is only an ideal, though. Despite a lack of empirical evidence confirming that certain types of commitment are the source of fear, on the basis of available theoretical deliberations, it can be assumed that fear and threat trigger the "have to" type of commitment (Bragg, 2002). Meanwhile, practical experience indicates that fear causes anticipative and excessive commitment in individuals, and not commitment itself, but uncontrolled emphasis put on commitment.

The "must" type of commitment occurs when employees have to work at a particular workplace because they either have no other option or for various reasons are strongly connected with the organization.

Fear also triggers anticipative commitment, i.e. commitment with no proper preparation, for example without employee training. In the 1990s, in a big stock exchange-listed company that was the Polish Quality Award winner, during the morning meeting of the management, the CEO said, "We're going to implement TQM and things will be different as of today, and if you do not know what it means, then you need to find out as soon as possible". This statement caused anxiety in the managerial staff. None of them had ever heard of TQM before. There had been no training or meeting dedicated to it before.

Excessive commitment of individuals causes suspicion and fear. A company owned by the town X employed a quality system representative who imposed very ambitious targets on himself. He wanted the company to become one of the best in the industry. Therefore, he developed various methods for measuring system effectiveness. The company promptly implemented an integrated system, the employees used the EFQM-consistent self-assessment model, and the balanced scorecard method. Rigorous process management principles were implemented. The personnel's competences were also assessed and quality training events were organized regularly. The representative was doing much more than he was required to do in accordance with his job description. Yet, in time, the representative's commitment was no longer respected; the employees were fed up with new tasks and the company management stopped supporting him. When an external benchmarking group was established, the representative's activity was categorized as a threat to the authority. He was perceived as someone aiming to promote themselves rather than to improve quality. He was very soon given a notice of termination.

Current research results concerning citizenship behavior constitute indirect evidence confirming that excessive commitment of individuals causes unnecessary tension (Klotz and Bolino, 2013).

Excessive emphasis put on commitment makes employees come up with fictitious solutions. Such a situation occurs where there is strong and completely unjustified pressure for quality improvement and changes. In a certain organization which was a Polish Quality Award winner, productiveness improvement groups were introduced. Commitment is one of the quality improvement methods used in TQM. Employees were expected to present ideas concerning improvements in the workplace and technological processes. An analysis of documents and their confrontation with actually implemented activities showed that huge pressure for commitment led to unethical behaviors. After some time employees started to put forward fictitious ideas, pretending their interest and commitment. Emphasis on commitment has to be adjusted to an organization's needs (Bugdol, 2010).

\section{Leadership}

Leadership is another principle of TQM. It is highlighted in very many publications (e.g. Oakland, 1995; Roberts, 2004; Calvo-Mora et al., 2005; Calvo-Mora et al., 2018). Leadership is believed to consist in an ability to not only motivate people and determine targets, but also 
eliminate fear (Zhao et al., 2015). Consequently, the question arises whether leadership is related to fear and if so, in what way.

Firstly, opinions presented by consultants and based on interviews prove that leadership is full of fear (Crosby, 2018). High quality in TQM very often results from leaders' commitment, from strong leadership. High quality is sometimes achieved under immense pressure which intensifies fear, conformity and suspicion. Fear exists when expectations are high of leaders who are thrown into their new role (Conquering Leadership Fears, 2018).

Secondly, besides being leaders, some superiors also manifest authoritarian behaviors. And authoritarian leadership causes fear, a sense of absence of self-confidence, which does not foster creativity because employees adopt various defensive attitudes, including employee defensive silence (Guo et al., 2018; Bugdol and Bortniczuk, 2018; Babalola et al., 2016).

Thirdly, individuals appointed to be leaders may have to deal with persons who are much more competent in certain management areas, and this may result in anxiety and fear (cf. Grenny, 2015).

Fourthly, when people deal with a very strong leader, a situation of uncertainty and fear can occur. Investors and employees are convinced that such a leader's absence is a risk to the organization's existence. This happens not only in the case of charismatic leaders, but also when such leaders control enterprises which are very complex in terms of their structure or objectives of business activities.

\section{Empowerment}

There are many definitions of empowerment; according to one of them, empowerment is the process of eliminating fear and all bureaucratic obstacles that make the decision process difficult (Hochman, 2005). Empowerment manifests itself in superiors demonstrating their belief that employee empowerment and the elimination of organizational and psycho-social barriers exert a positive influence on management effectiveness and efficiency. Various researches indicate that empowerment has a favorable impact on employees' trust in managers, reduces the costs of internal and external control, as well as transaction costs (Moye and Henkin, 2006). However, not all empowerment programs are successful, which was shown in the research conducted by Edward and Collinson (2002). Why can empowerment cause fear?

Firstly, because empowerment can be interpreted differently by employees and superiors. Superiors do not want to lose their power and demand increased efforts and responsibility from their subordinates. Employees want to have autonomy and freedom, but they also fear losing support (Hill and Huq, 2004). "Employees may resist empowerment for fear of taking on responsibilities or considering that empowerment is a mere rhetoric, while leaders/ managers can be reluctant to adopt empowerment, when decentralized power is seen as a threat" (Andrade et al., 2017, p. 79).

Secondly, empowerment has various dimensions: the structural dimension (e.g. flattening organizational structures), the mental dimension (understood as readiness to assume responsibility), the pedagogical dimension (connected with training and preparing people for changes). It is emphasized that structural empowerment needs to be supported by mental empowerment. Structural empowerment without any preparation of employees causes apprehension and anxiety. And as various researches prove, empowerment can be connected with nothing else but delegating new responsibilities (Korukonda et al., 1999). Summing up, in the initial stage of TQM and implementation of empowerment, fear results from apprehension of changes. It is caused by uncertainty concerning a new division of power and is connected with a low level of competence-based trust.
A review of problem of fear in TQM 
TQM

32,6

\section{Teamwork}

The need for teamwork is emphasized by many researchers (Oakland, 1995, p. 269). It is not the author's intention to undermine this need, but merely to indicate the risks connected with teamwork and the relations between this organizational form and fear. Let us take a look at quality circles. They have a voluntary character. The literature on the subject offers very many guidelines concerning successful implementation of quality circles (e.g. determination of objectives, regularity of meetings, support, etc.) (Jajoo and Kakkad, 2016). Numerous elements influence the effectiveness of the work of quality circles, for example members' self-esteem (Brockner and Hess, 1986). However, the question arises why this popular organizational form can be a source of fear. There are several reasons for this.

Firstly, the very process of group development, not only in the case of quality circles, is very dynamic. It comprises several stages such as the development stage, the turbulent stage - when group members can manifest mutual hostility and rebel against the existing rules and structures, the standards formation stage, the effectiveness stage, and the end of activity stage (Stoner et al., 2001). Fear appears mainly at the turbulent stage when team members can manifest mutual hostility and rebel against the existing rules and structures.

Secondly, a duality may occur in the case of quality circles, which was observed already in the 1980s (Goldstein, 1985). On the one hand, there may exist formal obligatory organizational forms, and on the other hand, teams are established. A lack of division of power, authority, and responsibilities, unequal selection of resources, etc. may cause conflicts and be a source of fear and threat for former groups of interest (however, a lot depends on the approval of ideas submitted by quality circles).

Thirdly, the voluntary character leads to many doubts (the effect of following the principle of "whoever is not with us is against us"). Participation in quality circles is voluntary, but it cannot be denied that it results also from compliance with the principle of cooperation and the fear of social exclusion. More recent researches prove that the fear of exclusion strongly encourages cooperation among workers, but it does not generate trust needed for cooperation (Kopányi-Peuker et al., 2018).

Fourthly, improper implementation of quality circles contributes to the decline of satisfaction in middle-level managers. Managers who are usually afraid that quality circles will take over their powers and authority frequently boycott the formation of quality circles, and consequently top management needs to specify the limits of the respective powers of managers and quality circle leaders very precisely (Morris and Haigh, 1994; Sethi, 2000). Such conflicts will not occur where quality circle leaders are functional managers, but such solutions are ineffective and are implemented against the logic of quality circles. It cannot be ruled out that some employees will treat quality circles as new opportunities to pursue their careers. , Conflicts of interests occur where functional structures are maintained and such conflicts constitute a risk to the position of middle-level managers.

Previous research has shown that fear has its sources, among others, in commitment and uncontrolled pressure to show commitment, pressure to achieve high quality, authoritarian leadership or a lack of mental empowerment. Looking for the causes of fear in the TQM components, researchers may extend literature studies with additional TQM components, formulate hypotheses for each component or conduct empirical research.

However, the author proposes that research should focus on the role of commitment in TQM. Why? Findings made so far indicate that the decisive majority of TQM programs fail to achieve success because of insufficient or improper commitment (Stabler, 1995; Kolodny, 1995; Waller and Ahire, 1996; Jacokes, 1996; Bugdol, 2011). The proper attitude of managers, and particularly chief executives, consists in providing support and reducing uncertainty (Deming, 1986). Therefore, the following hypothesis can be formulated: 
The higher the level of top management's commitment, the lower the level of fear in employees.

\section{The causes and consequences of fear}

The aforementioned researches and theoretical deliberations make it possible to distinguish several types of fear and their consequences. The division of the types of fear presented here takes into consideration the components of TQM. This means that if, for instance, the fear of exclusion is mentioned, then it is fear resulting from teamwork, and fear spreading to employees due to improper management styles is fear resulting from inappropriate leadership, etc.

The fear of changes is the best examined type of fear (Stabler, 1995; Kolodny, 1995; Soltani et al., 2005). It is caused by the lack of knowledge of changes and their purpose, but it results from apprehension concerning future employment, from uncertainty (many restructuring programs end with employees being made redundant or transferred). The fear of changes causes other types of fear, for example the fear of learning (Weeks et al., 2004). Consequently, it leads to a fall in the number of pro-innovative initiatives (Dziadkiewicz and Juchniewicz, 2013) and difficulties with the implementation of changes such as process improvements (Morris, 2015).

Another type of fear is the fear of assessment and of failure to achieve planned results. It is fostered by the determination of standards, quantitative objectives, and management by objectives (Deming, 1986). It impairs cooperation and makes teamwork difficult. This type of fear causes people to falsify data, sucks out their inborn internal motivation, and stifles their motivation to learn (Deming, 2012).

The third type of fear is the fear of losing power in an organization (Walle and Ahire, 1996). Research concerning quality circles also focuses on this type of fear (Morris and Haigh, 1994). At the initial stage of TQM implementation, middle-level managers are uncertain about their positions and afraid of losing employment. By applying the process approach and teamwork, TQM fosters changes in the organizational structure. However, previous findings indicate that in TQM, teams are more integrated with the organizational structure, and the reduction of hierarchies in organizational structures fosters the integration of working groups. Supervision should be reduced and a great deal of autonomy and resources should be assigned to teams (Angeles Escriba-Moreno and Canet-Giner, 2006). When changes do take place in the structure, the implementation of TQM programs has a positive impact on the autonomy of middle-level managers (Psychogios et al., 2009). In the individual dimension, the consequences of this type of fear can include searching for new employment, a decline in motivation and satisfaction or an improper use of power, which can all be sources of other types of fear. When one person is in a position to influence another person's future, two potential problems can appear: an improper use of power by managers and employees' negative attitude towards those holding power (Jacokes, 1996). The fear of losing power may lead to unethical or even criminal actions, for example sabotage (Taher and Krotov, 2016), or hinder knowledge sharing processes (Oliveira et al., 2019).

The fourth type of fear is fear spreading to employees due to improper management styles (cf. Babalola et al., 2016; Guo et al., 2018; Bugdol and Bortniczuk, 2018). The consequences of this type of fear include a clear decline in the number of undertaken preventive and corrective measures, the appearance of various defensive attitudes (including the disappearance of communication). The authoritarian style of TQM implementation would be disastrous (Nwabueze, 2011). For organizations applying TQM, transformational leadership is the most appropriate option (Sălăgean, 2014).

The fifth type of fear is the fear of other people (e.g. a group of co-workers). It affects leaders (Grenny, 2015) whose level of competence or competence trust is too low, but it can
A review of problem of fear in TQM

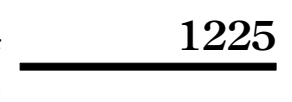


TQM 32,6

also be caused by social facilitation, that is tension resulting from the presence of other people and the possibility of their assessment of our activities. Tension resulting from the presence of other people causes fear and, consequently, such people have problems with performing difficult tasks (e.g. tasks consisting in detecting the primary causes of quality mistakes) (Aronson et al., 1997). Since leadership is very important in TQM, consequences of this type of fear can include low group cohesion, a lack of coordination, insubordination, poor results of quality improvement or no quality improvement at all. "The result of this fear is the attempt to decode the other by enclosing her in an alienated and standardized identity" (Prieto, 2015, p. 297). In view of people's aversion to being criticized by others or others' competences being overestimated, this type of fear hinders decision making processes (Grenny, 2015).

The sixth type of fear is the fear of punishment. There are formal punishments resulting from codes and work regulations, but there are also many informal forms of punishment in organizations. Employees were punished for lack of quality in the past (Drummond, 1998), and nowadays they are also punished for this. The most common form of punishment is to deprive them of a quality bonus (Bugdol, 2018a). It is not taken into account that quality depends on all employees' efforts, and the causes of quality decline are found in not only the social but also the technical system. Many researches indicate that punishment has less impact on changes in behaviors than rewards (Tremblay et al., 2013). It has been shown that changes in employee behaviors resulting from punishments are immediate but usually shortlasting. They are also limited due to the side effects of punishment, for instance, emotional reactions of people on whom sanctions have been imposed (Connellan, 1978). Where employees are punished, the tendency to propose improvement-oriented activities decreases (Bugdol and Bortniczuk, 2018). Punishment, in particular if regarded as unfair, leads to the destruction of social capital, and, consequently, of motivation, trust and satisfaction (as justice is the basis of trust which, in turn, is one of the elements of social capital). Employees can manifest unethical and counter-productive behaviors (making a decision to leave the organization, a dissatisfied employee experiencing injustice can undertake activities aimed at reducing the value of the company or destroying its assets) (Bugdol, 2018b, pp. 92-94). Fear of punishment turns out to be positively related to aggression and negatively related to prosocial behavior (Facing guilt: Role of negative affectivity, need for reparation and fear of punishment in leading to prosocial behavior and aggression (Caprara et al., 2001)).

The seventh type of fear, relatively insufficiently identified, is the fear of exclusion (Kopányi-Peuker et al., 2018). Researches focusing on quality circles have shown the existence of this type of fear. The fear of exclusion strongly encourages cooperation among workers, but it does not generate the trust needed for cooperation once the fear of exclusion is lifted (Kopányi-Peuker et al., 2018).

Table 1 indicates the sources and consequences of fear for each type of fear. In this case, existing publications allow to identify the potential consequences of fear (which of course requires further in-depth empirical research).

The literature studies performed pointed to various sources of fear that may be present in individual components of TQM. In this case, however, previous studies do not indicate the potential consequences of fear. Therefore, the next table contains only selected components of TQM and sources of fear - which should also be confirmed in further empirical studies (see Table 2).

Organizations following TQM may have to deal with the fear of changes, assessment, failure to achieve planned results, loss of power, punishment, exclusion from a group or organization, as well as the fear experienced by employees due to improper management styles. In practice, particular types of fear complement each other and occur with different frequency in different organizations. However, the fear of assessment, punishment or loss of power should not occur in organizations following the TQM principles. The fear of loss of power usually takes place during a period of structural changes or TQM implementation. It 
Types of fear
Fear of changes Stabler (1995);
Kolodny (1995); Soltani et al. (2005)

Kolodny (1995); Soltani et al. (2005) knowledge of changes and their purposes; it results from uncertainty about stability of employment

The fear of assessment and of failure to achieve planned results Deming (1986)

The fear of losing power in an organization Walle and Ahire (1996)

The fear experienced by employees due to improper management styles (Nwabueze,2011; Babalola et al., 2016; Guo et al., 2018; Bugdol and Bortniczuk, 2018)

The fear of others Grenny (2015)

Causes standards, quantitative objectives and management by objectives

The use of the process-based approach and teamwork facilitates changes in the organizational structure, which constitutes a threat to middlelevel managers Angeles EscribaMoreno and Canet-Giner, (2006)

This type of fear is connected with the use of autocratic management styles (e.g. Nwabueze (2011)

A low level of competences or
Consequences

It makes the implementation of various quality programs difficult. The fear of changes causes other types of fear, for example the fear of learning Weeks et al. (2004) It leads to a fall in the number of pro-innovative initiatives Dziadkiewicz and Juchniewicz (2013) and difficulties with the implementation of changes such as process improvements Morris (2015)

It is fostered by determination of competence trust in the case of leaders Grenny (2015); social facilitation in the case of all employees
It impairs cooperation and makes teamwork difficult Deming (1986) This type of fear causes people to falsify data, sucks out their inborn internal motivation and stifles their motivation to learn Deming (2012)

In the individual dimension, the can include searching for new employment, decline of motivation and satisfaction or improper use of power, which can be a source of another type of fear. Employees' negative attitude towards those holding power Jacokes (1996). The fear of losing power may lead to sabotage Taher and Krotov (2016) or hinder knowledge sharing processes Oliveira et al. (2019) The consequences of this type of fear include a clear decline of the undertaken preventive and corrective measures, adopting various defensive attitudes (including disappearance of communication) (Guo et al. (2018); Bugdol and Bortniczuk (2018) Because of people's aversion to being criticized by others or others' competences being overestimated, this type of fear hinders decisionmaking processes Grenny (2015) "The result of this fear is the attempt to decode the other by enclosing her in an alienated and standardized identity" Prieto (2015), p. 297). People experiencing facilitation have problems with performing difficult tasks Aronson et al. (1997), p. 677 consequences of this type of fear

\section{A review of problem of fear in TQM}

1227
Table 1.

Types of fear - their causes and consequences

(continued) 
TQM 32,6

\section{8}

The fear of exclusion KopányiPeuker et al. (2018)

Table 1.

Types of fear
The fear of punishment Drummond
(1998); Tremblay et al. (2013);
Bugdol (2018a)

Causes

Formal and informal punishments (including a progressive punishment system)
Consequences

Where employees are punished, the tendency to propose improvement-oriented activities decreases Bugdol and Bortniczuk (2018). Punishments lead to the destruction of social capital. Employees can manifest unethical and counter-productive behaviors Bugdol (2018b). Fear of punishment turns out to be positively related to aggression and negatively related to prosocial behavior Caprara et al. (2001) The fear of exclusion strongly encourages cooperation among workers, but it does not generate the trust needed for cooperation once the fear of exclusion is lifted Kopányi-Peuker et al. (2018)
This type of fear is related to personality traits, for example, a strong need to belong to a group, especially to an attractive one. Its appearance may be facilitated by a team-based work organization system

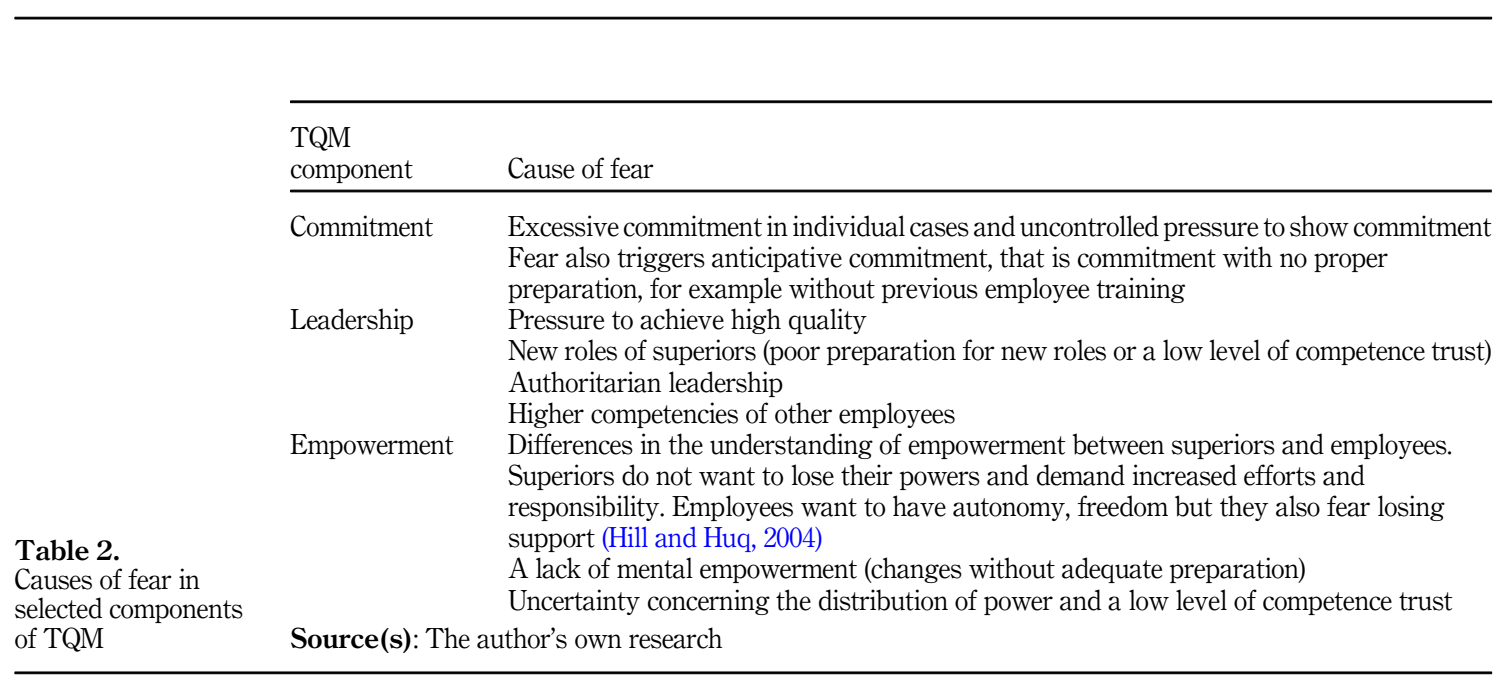

has been shown, however, that teamwork is one of the components of TQM. Therefore, the following hypothesis can be proposed:

The more types of teamwork in an organization, the higher the fear of exclusion.

The fear of exclusion is rarely the subject of research, but because of various forms of teamwork, tasks, and functions of commitment in TQM, it deserves special attention.

Research shows that there are various causes of fear, for example personal, situational, embedded in social processes or resulting from the lack of knowledge. Dividing these causes into groups, one can assume that the majority of them are connected with the lack of managerial competences. These are competences which, to a certain extent, reduce uncertainty, allow the 
proper designing of organizations, ensure efficient team management and effective communication. E. Deming was of the opinion that the majority of problems with quality are the fault of managers. Thus, the following hypothesis can be put forward:

The causes of fear have their roots in the lack of managerial competences.

Of course, the notion of managerial competences itself required conceptualization. But it can be assumed that what counts in TQM is employee empowerment, support for teamwork, coaching, employee commitment, as well as continuous learning and improvement.

The consequences of fear are related to the types of fear. Research indicates that fear causes decline of motivation and satisfaction, hinders decision making, constitutes a barrier for cooperative behaviors and prevents the implementation of both prophylactic and corrective measures. Thus, the following hypothesis can be suggested:

The ultimate consequence of fear is the lack of actions that lead to improvement.

\section{The possibilities and methods of fear reduction}

If the literature on the subject discusses any fear reduction methods, they usually concern the fear of changes, which is regarded as important in TQM. Authors often emphasize the necessity to ensure proper communication (Thor, 1993) and a changefriendly environment, that is an adequate level of trust and empowerment, which can be difficult to achieve (Ward and Warner, 1996). According to researchers, managers' attitudes are no less important; they should be supportive, honest, informative, nononsense and enthusiastic (O'Neal, 2018). Important practical functions are also fulfilled by agents of change (Robison, 2011). Therefore, in order to minimize the fear of changes, if these changes are oriented towards quality improvement, employees should be provided with information concerning the purpose of changes and positive examples of changes implemented in other companies. They should be involved in the process of change and informed about the achievement of objectives and the implementation of particular stages of the process.

Eliminating or minimizing the fear of losing power is very difficult. The implementation of TQM results in structural changes consisting in the introduction of either quality teams (e.g. Angeles Escriba-Moreno and Canet-Giner, 2006) or the process-based approach (Oakland, 1995). Expectations regarding managers' behavior undergo continual changes (e.g. Bäckström et al., 2011). The fear of losing power can be regarded as the fear of losing one's social position in a group. There are no publications indicating how this type of fear could be minimized but, taking into consideration changes taking place under the influence of TQM, it can be stated that minimizing such fear could consist in entrusting managers with new process owner functions, quality team leader duties, or new tasks connected with sustainability programs (Dervitsiotis, 2005).

Another type of fear is the fear of assessment and failure to achieve planned results. Referring to the views of E. Deming (1986), it can be stated that fear reduction consists in giving up the use of employee rankings and time-based standards. Deming also emphasized the role of superiors' attitudes, claiming that every leader's basic duty was to remove fear from the workplace. Based on the identification of its primary causes, it can be claimed that fear reduction should consist in undertaking tasks aimed at the improvement of all standards and procedures, including grassroots initiatives. An assessment of the cohesion of objectives and the determination of objectives together with employees are very important. If remuneration depends on the achievement of objectives, then such objectives need to be diversified. Apart from quantitative objectives, qualitative and environmental ones have to be taken into account as well (cf. Carson and Carson, 1993).

The literature does not provide examples directly illustrating the reduction of fear resulting from improper management styles. Nevertheless, before such managers are
A review of problem of fear in TQM

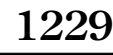


TQM 32,6

1230

eliminated, which is obviously necessary in light of HR rules, it is necessary to conduct detailed analyses of their competences (such as cooperation skills, provision of health-related information, support for employees, etc.) (Bugdol, 2011). Behavior-modifying training is less effective (cf. Mayer and Russel, 1987). The author's experience related to the implementation of the TQM concept shows that very good results can be achieved by analyzing employees' reasons for submitting a letter of resignation. Interviews with dismissed employees can provide valuable knowledge of their superiors' actual behavior.

There are various reasons for people being afraid of others. It is obvious that not everybody has the skills necessary to mix easily with others or cooperate within employee teams. In TQM the ability to work in teams constitutes a very important skill, but people are shy, are afraid of something, lack motivation or do not like working in groups (Schullery and Gibson, 2001). One of the major reasons for the poor functioning of a group is its members' fear of conflict and hostility (McGregor, 1960). Fear is one of the factors hindering teamwork (Whitaker, 2009). In order to minimize the risk of employing improper candidates as team members, recruiters can use various tests diagnosing teamwork skills (McClough and Rogelberg, 2003). Employee opinion surveys and team monitoring are less effective tools used to mitigate this risk. Conducted researches prove that leaders' skills at conflict management, communication support, assistance offered to other people and recognition of their contribution are particularly important (Aronson et al., 2014). However, the development of such skills is very difficult as it depends on many personality and contextual factors. Most probably, the narrower the scope of assessment, the smaller the fear of other people. Therefore, organizations implementing TQM cannot use employee rankings, which was also discussed by Deming. To some extent (due to cost intensiveness and methodological limitations), people experiencing facilitation can be diagnosed and supported.

In order to diminish the fear of punishment and to ensure the undisturbed course of quality improvement processes, positive discipline models should be applied (Grote, 2006). When a problem arises, employees are not punished, but together with their superiors they search for methods of avoiding similar problems in the future. Joint corrective measures are undertaken.

The fear of exclusion is very difficult to reduce. Its real causes (personality problems, inappropriate HR management, excessive group cohesion) have to be identified. Some studies indicate that the intensity of this fear may decrease if employees are employed on a permanent basis (Kopányi-Peuker et al., 2018) (see Table 3).

The table above includes all identified types of fear. In the case of the causes of fear rooted in the components of TQM, it should be remembered that the application of structural empowerment requires mental empowerment. Furthermore, not all employees will be able to cope with new tasks, powers and duties.

With respect to leadership, it is necessary to decrease pressure put on managers to achieve high quality, to apply long-term perspectives, and to reduce top management mobility. New tasks can be assigned to managers only after they have been provided with necessary support (information, training). It is also necessary to strengthen competence trust (e.g. by assigning employees new and challenging tasks). Furthermore, it is recommended to follow all rules applicable to the fear experienced by employees due to improper management styles.

In the case of teamwork, special attention should be paid to alleviating the fear of others and the fear of exclusion. Additionally, it is necessary to prevent any unequal, and thus unfair, allocation of resources, to ensure the authentic voluntary character of participation in quality circles, and to assign powers and duties unambiguously. In the case of commitment, fear is fostered mainly by anticipative commitment; therefore, TQM has to be a continuous process as opposed to dynamic but short-lived actions.

Writing about fear and its reduction, one should remember about the principle applicable to organizational values and virtues. Namely, that both an absence of fear and an excess of fear are 


\section{Types of fear \\ The fear of changes}

The fear of losing power

The fear of assessment and of failure to achieve planned results

The fear overcoming employees due to improper management styles

The fear of others
Methods

Ensuring proper communication Thor (1993)

Ensuring a change-friendly environment, that is an adequate level of trust and empowerment Ward and Warner (1996). Ensuring managers' attitudes that are supportive, honest, informative, no-nonsense and enthusiastic O'Neal (2018)

Introducing agents of change Robison (2011)

Entrusting managers with new process owner functions, quality team leader duties, or new tasks connected, for example, with sustainability programs Dervitsiotis (2005)

Giving up the use of employee rankings and time-based standards Deming (1986)

Proper attitudes of managers (every leader's basic duty is to remove fear from the workplace). Apart from quantitative objectives, qualitative and environmental ones have to be taken into account as well Carson and Carson (1993)

Conducting detailed analyses of managers' competences (such as cooperation skills, provision of healthrelated information, support for employees, etc.) Bugdol (2011) Organizing behavior-modifying training (cf. Mayer and Russel (1987) Analyzing employees' reasons for submitting a letter of resignation Using various tests diagnosing teamwork skills McClough and Rogelberg (2003)

Ensuring managers' behavior consisting in communication support, assistance offered to other people and recognition of their contribution Aronson et al. (2014). Giving up the use of rankings Deming (1986)

Conducting employee opinion surveys and team monitoring
Limitations

Providing a change-friendly environment and managers with required attitudes is a very difficult task because people value stability and resist changes

It is very difficult to implement changes in such a manner so as not to bring about any losses in the case of particular employees (loss of position, remuneration, prestige), or to minimize these losses

If managers start to lose power, they may create separate strict control systems or interfere with the work of new teams

Apart from qualitative objectives, there are many quantitative ones related to a short-term perspective, an employee assessment system or a remuneration system, which may have a considerable negative impact on fear reduction

Limitations result from deficiencies in competence assessment methods Opinions on the effectiveness of behavior-modifying training are not always positive

The development of proper attitudes is very difficult because it is determined by many personal and contextual factors

Psychological tests tend to be ineffective - they diagnose behaviors that are not necessarily characteristic of the work environment

Table 3.

Selected proposals for reducing fear in the TQM concept 
TQM 32,6

The fear of exclusion

\begin{tabular}{ll} 
Types of fear & Methods \\
\hline The fear of punishment & $\begin{array}{l}\text { Replacing a progressive discipline } \\
\text { system with a positive discipline } \\
\text { system. Grote (2006) }\end{array}$
\end{tabular}

Improving employment security, for example by offering employees contracts for an indefinite period of time Kopányi-Peuker et al. (2018) Diagnosing causes by means of tests examining personality, teamwork skills etc.

\section{Limitations}

Apart from formal punishments that can be controlled, organizations can have complex systems of informal punishments. Fear can also be caused by situational factors

The fear of exclusion is very difficult to eliminate. Its real causes have to be identified (Are they personality problems, inappropriate HR management or excessive group cohesion)

Table 3.

Source(s): The author's own research

something negative. Research conducted so far indicates that fear is used to motivate employees (e.g. Kotter, 1995) or to implement changes (Bailey, 1997). Fear is a tool used to discipline employees, to force them to behave in a particular way, but also to modify their behaviors. The role of fear, in particular the fear of death, is used in various programs aimed at the improvement of work safety, and even in "zero defects" programs (Halal and Lasken, 1980). Fear manifested by managers may result in positive changes in company share prices. Such fear may cause top managers to consider particular programs or initiatives aimed at improving operating results, which may eventually influence the share price level. Nevertheless, fear has a temporary character and disappears quickly (Akansu et al., 2017). On the basis of the conducted literature review, it can be shown that the most often used methods of fear reduction include proper communication, ensuring a friendly work environment, allocating new tasks, giving up rankings and time based standards, as well as assessing managerial/leadership competences and personality traits. The common denominator of such actions is managerial competences and thus, the following hypotheses can be proposed:

The higher the level of managerial competences, the lower the level of fear.

\section{Conclusion}

On the basis of the conducted research, it can be concluded that the sources of fear are located in the very essence of TQM, that is in its selected components such as commitment, leadership, empowerment, teamwork. Fear appears when, for various reasons, TQM is improperly implemented and maintained or when available resources are badly allocated (e.g. wrong selection of quality team members). It appears when only structural rather than mental empowerment is applied, when employees have contradictory expectations with regard to empowerment, in the case of excessive commitment of particular employees and/or the musttype commitment, or when too much emphasis is placed on commitment. Fear is also caused by authoritarian leaders or by the irreplaceability of leaders. Organizations following TQM may have to deal with the fear of changes, assessment, failure to achieve planned results, loss of power, others, punishment, exclusion from a group or organization, as well as the fear experienced by employees due to improper management styles. The consequences of fear are related to the types of fear. And thus, the fear of changes causes other types of fear such as the fear of learning, which, in turn, reduces the number of pro-innovative actions and hinders the implementation of changes or the improvement of processes. The fear of assessment and failure to achieve planned results impairs cooperation and makes teamwork difficult. It causes people to falsify data, sucks out their inborn internal motivation, and stifles their motivation to learn. 
The consequences of fear of losing power can include searching for new employment, decline of motivation and satisfaction, or improper use of power, which can be a source of another type of fear.

The consequences of fear experienced by employees due to improper management styles include a clear decline of undertaken preventive and corrective measures, adopting various defensive attitudes (including disappearance of communication). The fear of others hinders decision making processes and causes difficulties with the performance of more challenging tasks.

The fear of punishment is the cause of counterproductive behaviors. It facilitates aggression and impedes the manifestation of pro-social behaviors. The fear of exclusion strongly encourages cooperation among workers, but it does not generate the trust needed for cooperation once the fear of exclusion is lifted.

Fear can be reduced in many different ways. The most often mentioned methods include ensuring proper communication and a change-friendly environment, that is an adequate level of trust and empowerment - in the case of the fear of changes; entrusting employees with new functions and tasks - in the case of the fear of losing power; giving up employee rankings and time-based standards - in the case of the fear of assessment and failure to achieve planned results; ensuring monitoring, BMT training and competence assessment - in the case of the fear overcoming employees due to improper management styles; using tests diagnosing teamwork skills, conducting employee opinion surveys and team monitoring - in the case of the fear of others; introducing positive discipline models - in the case of the fear of punishment; increasing the sense of job and employment security - in the case of the fear of exclusion.

The reflections included in the paper may become useful for quality management practitioners who want to avoid making mistakes resulting in fear, an emotion making quality improvement difficult.

In summary, the general conclusion can be drawn that the source of the majority of problems with fear (caused by external factors) is the lack of managerial competences, that is the lack of knowledge and skills concerning change implementation, communication, employee team building, empowerment or work organization. Obviously, managerial competences do not guarantee the absence of fear, but they may help to reduce it. But maybe Deming was right? He claimed that the majority of errors resulted from improper management and conditions inherent in a given system.

\section{Limitations and suggestions for future research}

The major limitations of the proposed concepts and the presented research results ensue from the complexity of the problem of fear. The conducted analysis of the literature indicates that authors use the notions of fear and apprehension interchangeably. Fear in TQM is obviously related to a sense of uncertainty, some anxiety about changes, risks and expectations. Therefore, it is difficult to declare unambiguously when authentic fear occurs. The notion of fear needs to be conceptualized; it is necessary to conduct a process aimed at establishing precisely what is meant by fear. What should be determined is its indicators, that is so-called signs of the presence or absence of a given concept (Babbie, 2003). Fear, its sources, manifestations and consequences are difficult to study; a dynamic approach would have to be adopted, and long-term research projects would have to be conducted. Perhaps this explains why there are no empirical studies concerning these problems in the science of quality.

Not all of the previously diagnosed manifestations of fear are caused by fear itself. This emotion is accompanied by overall emotional tension, as well as a decline in trust and commitment.
A review of problem of fear in TQM

1233 
TQM 32,6

Another limitation is that this paper does not identify the causes and manifestations of fear in all TQM components, and they are certainly included in the broadly understood culture of quality, communication, and training.

Only the negative consequences of fear are presented in the paper. It is believed, however, that fear is a tool for disciplining people and enforcing certain types of behavior on them (Keeling, 2011). Fear can also play a motivational function. For many people, fear, in particular the fear of failure (for instance in sports), can be a strong motivator. There is, however, an invisible border between giving feedback and intimidating. People who want to become successful cannot be afraid of receiving negative opinions (Birchfield, 2011).

The proposed methods of fear reduction are rather limited. In fact, certain causes of fear (team formation processes, individual predispositions of employees, contradictory expectations concerning the change process) are beyond anybody's control. Training and information campaigns increasing employees' awareness are merely prerequisites of positive changes, but they do not guarantee them. There are very different opinions concerning the usefulness of behavior-modifying training. There is no clear evidence confirming that this form of training is more effective than others (Mayer and Russel, 1987). Detailed solutions concerning the positive discipline model are not free of drawbacks, either. Sanctions used in the positive discipline model (disciplinary talks, leaves, supervision over an employee for a specified period of time, days off) can turn out to be more severe for some employees than a caution or reprimand. Supervision over an employee can result in their making more mistakes (they will have no opportunity to learn from their own mistakes, which will not foster quality improvement). Human resources management procedures can and should be improved, but their effectiveness depends on numerous factors, such as the level of trust, the organizational climate or the psychological contract. It should also be noted that the selectively described methods of fear reduction are in fact the methods of strengthening an organization's social potential (but the problem is that fear has not been sufficiently studied and there are no methods oriented towards fear reduction, perhaps because of the complexity of the problem).

There are many possibilities of further research on the phenomenon of fear. For example, it is possible to undertake empirical research based on the observations and hypotheses presented in this paper. Research can focus on the causes of fear in other TQM components, for example in the process approach. It could be interesting to examine the treatment (including intimidation) of employees in the short- and long-term perspectives in view of $\mathrm{E}$. Deming's emphasis put on the long-term orientation of TQM. Another suggestion concerns research on the influence of top managers' remuneration systems on their employee management methods, including the use of intimidation or coercion to achieve quick spectacular results. Pressure exerted by customers can also represent an interesting research subject. An examination of customers' needs and expectations plays an important role in TQM. However, such needs and expectations undergo changes, which can result in tension and, consequently, fear. Thus, the problem of fear certainly deserves further thorough and detailed research.

\section{References}

Akansu, A., Cicon, J., Ferris, S.P. and Sun, Y.(2017), "Firm performance in the face of fear: how CEO moods affect firm performance", Journal of Behavioral Finance, Vol. 18 No. 4, pp. 373-389.

Andrade, J., Mendes, L. and Lourenço, L. (2017), "Perceived psychological empowerment and total quality management-based quality management systems: an exploratory research”, Total Quality Management and Business Excellence, Vol. 28 Nos 1/2, pp. 76-87.

Angeles Escriba-Moreno, M. and Canet-Giner, M.T. (2006), "The combined use of quality management programs and work teams: a comparative analysis of its impact in the organizational 
structure”, Team Performance Management: An International Journal, Vol. 12 Nos 5/6, pp. 162-181.

Aronson, E., Wilson, T.D. and Akert, R.M. (1997), Psychologia Społeczna. Serce I Umyst, Zysk I S-ka, Zysk i S-ka, Poznań.

Aronson, Z.H., Dominick, P.G. and Wang, M. (2014), "Exhibiting leadership and facilitation behaviors in NPD project-based work: does team personal style composition matter?", Engineering Management Journal, Vol. 26 No. 3, pp. 25-35.

Arunachalam, T. and Palanichamy, Y. (2017), "Does the soft aspects of TQM influence job satisfaction and commitment? An empirical analysis", The TQM Journal, Vol. 29 No. 2, pp. 385-402.

Babalola, M.T., Garba, A.O., Guo, L. and De Schutter, L. (2016), “A test of a dual mediation pathway linking authoritarian leadership to employee creativity", Academy of Management Annual Meeting Proceedings, Vol. 2016 No. 1, p. 1.

Babbie, E. (2003), Badania Spoteczne W Praktyce, PWN, Warszawa.

Bäckström, I., Ingelsson, P. and Wiklund, H. (2011), "Learning from others to adapt quality management to the future", Total Quality Management and Business Excellence, Vol. 22 No. 2, pp. 187-196.

Bailey, G. (1997), "Fear is nothing to be afraid of", Wall Street Journal, January, Vol. 229 No. 18, pp. 22.

Birchfield, R. (2011), "Sean Fitzpatrick No need to be liked", New Zealand Management, Vol. 58 No. 7 , pp. 30-32.

Bloom, N., Propper, C., Seiler, S. and Van Reenen, J. (2015), "The impact of competition on management quality: evidence from public hospitals", Review of Economic Studies, Vol. 82 No. 2, pp. 457-489.

Bragg, T. (2002), "Improve employee commitment", Industrial Management, Vol. 44 No. 4, pp. 18-21.

Brockner, J. and Hess, T. (1986), "Self-esteem and task performance in quality circles", Academy of Management Journal, Vol. 29 No. 3, pp. 617-623.

Bugdol, M. (2010), Wymiary I Problemy Zarzadzania Organizacja Oparta Na Zaufaniu, Wyd UJ, Kraków.

Bugdol, M. (2011), Zarzadzanie Pracownikami - klientami Wewnętrznymi W Organizacjach Projakościowych, Difin, Warszawa.

Bugdol, M. (2018a), "Problemy z wynagradzaniem za jakość”, Problemy Jakości, Vol. 8, pp. 12-17.

Bugdol, M. (2018b), A Different Approach to Work Discipline: Models, Manifestations and Methods of Behavior Modification, Palgrove Macmillian, Cham.

Bugdol, M. and Bortniczuk, K. (2018), "Normatywne i społeczne czynniki wpływajace na podejmowanie działań doskonalacych w systemie zarzadzania jakościa”, in Skrzypek, E. (Ed.), Zarzadzanie Organizacja W Warunkach Różnorodności, UMSC, Lublin.

Calvo-Mora, A., Leal, A. and Roldán, J.L. (2005), "Relationships between the EFQM model criteria: a study in Spanish universities", Total Quality Management and Business Excellence, Vol. 16, pp. 741-770.

Calvo-Mora, A., Domínguez-CC, M. and Criado, F. (2018), "Assessment and improvement of organisational social impact through the EFQM Excellence Model”, Total Quality Management and Business Excellence, Vol. 29 Nos 11/12, pp. 1259-1278.

Caprara, G.V., Barbaranelli, C., Pastorelli, C., Cermak, I. and Rosza, S. (2001), "Facing guilt: role of negative affectivity, need for reparation, and fear of punishment in leading to prosocial behavior and aggression”, European Journal of Personality, Vol. 15 No. 3, pp. 219-237.

Carmody, J.M. (1994), "Overhauling corporate culture to improve productivity”, Industrial Engineering, Vol. 26 No. 5, p. 14.

Carson, P.P. and Carson, K.D. (1993), "Deming versus traditional management theorists on goal setting: can both be right?", Business Horizons, Vol. 36 No. 5, p. 79.

Connellan, T.K. (1978), How to Improve Human Performance: Behaviorism in Business and Industry, Harper and Row, New York, NY.
A review of problem of fear in TQM 
TQM 32,6

Craig, J.H.S. and Lemon, M. (2008), "Perceptions and reality in quality and environmental management systems: a research survey in China and Poland", The TQM Magazine, Vol. 20 No. 3, pp. 196-208.

Crosby, K. (2018), "Fearless leadership is full of fear", Central Penn Business Journal, Vol. 34 No. 48 , pp. 1-10.

Conquering Leadership Fears (2018), "Leadership excellence essentials”, Vol. 35 No. 7, pp. 60-61.

Deming, W.E. (1986), Out of the Crisis, MIT Center for Advanced Engineering Study, MA, Cambridge.

Deming, W.E. (2012), Nowa Ekonomia Dla Przemystu, Rzadu, Edukacji: The New Economics For Industry, Government, Education, OpExBooks.Pl, Wrocław.

Dervitsiotis, K.N. (2005), “Creating conditions to nourish sustainable organizational excellence”, Total Quality Management and Business Excellence, Vol. 16 Nos 8/9, pp. 925-943.

Drummond, H. (1998), W Pogoni Za Jakościa, Total Quality Management, Dom Wydawniczy ABC, Warszawa.

Dziadkiewicz, A. and Juchniewicz, P. (2013), "Koncepcja zarządzania zmiana w organizacji. Idea of change management in business environment", Research Papers of the Wroclaw University of Economics / Prace Naukowe Uniwersytetu Ekonomicznego we Wroclawiu No. 277, pp. 15-23.

Edwards, P. and Collinson, M. (2002), "Empowerment and managerial labor strategies", Work Occupations Nos 29/3, pp. 272-299.

Gitlow, H.S. (1994), “Dr. Deming's theory of management”, American Statistician, Vol. 48 No. 3, p. 197.

Goldstein, S.G. (1985), "Organizational dualism and quality circles”, Academy of Management Review, Vol. 10 No. 3, pp. 504-517.

Gordon, J. (1995), "Follow the money", Training, Vol. 32 No. 10, p. 12.

Greasley, K., Bryman, A., Dainty, A., Price, A., Soetanto, R. and King, N. (2005), "Employee perceptions of empowerment”, Employee Relations, Vol. 27 No. 4, pp. 354-368.

Grenny, J. (2015), “Are you sure you want to be a manager?”, Harvard Business Review Digital Articles, pp. 2-4, (accessed 22 September 2015).

Grote, D. (2006), Discipline without Punishment, AMACOM, New York, NY.

Guo, L., Decoster, S., Babalola, M.T., De Schutter, L., Garba, O.A. and Riisla, K. (2018), “Authoritarian leadership and employee creativity: the moderating role of psychological capital and the mediating role of fear and defensive silence", Journal of Business Research, Vol. 92, pp. 219-230.

Halal, W.E. and Lasken, R.A. (1980), "Management applications of catastrophe theory", Business Horizons, Vol. 23 No. 6, pp. 35-43.

Hill, F.M. and Huq, R. (2004), "Employee empowerment: conceptualizations, aims and outcomes", Total Quality Management and Business Excellence, Vol. 15 No. 8, pp. 1025-1041.

Hochman, L. (2005), "Magnetic appeal”, Personnel Today, Vol. 9 No. 27, pp. 4-5.

Jacokes, L.E. (1996), "The essential principle to keep in mind is understanding the importance of individual control in reducing workplace fear 'Driving out fear' helps workplace thrive”, Grand Rapids Business Journal, Vol. 14 No. 23, p. 15.

Jajoo, N. and Kakkad, A. (2016), "Sustaining and institutionalizing quality circles", Journal for Quality and Participation, Vol. 39 No. 1, pp. 9-12.

Jayaram, J., Ahire, S. and Dreyfus, P. (2010), "Contingency relationship of firm size, TQM duration, unionization and industry context on TQM implementation - a focus on total effects", Journal of Operations Management, Vol. 28 No. 4, pp. 345-355.

Keeling, J.M. (2011), Fear Is Not a Lobbying Tactic, ESOP Report.

Klotz, A.C. and Bolino, M.C. (2013), "Citizenship and counterproductive work behavior: a moral licensing view", Academy of Management Review, Vol. 38 No. 2, pp. 292-306.

Kolodny, D. (1995), "Driving fear out of labor-management relationships", Journal for Quality and Participation, Vol. 18 No. 3, p. 6. 
Kopányi-Peuker, A., Offerman, T. and Sloof, R. (2018), "Team production benefits from a permanent fear of exclusion", European Economic Review, Vol. 103, pp. 125-149.

Korukonda, A.R., Watson, J.G. and Rajkumar, T.M. (1999), "Beyond teams and empowerment: a counterpoint to two common precepts in TQM", SAM Advanced Management Journal, Vol. 64 No. 1, pp. 29-36.

Kotter, J.P. (1995), "Leading change: why transformation efforts fail", Harvard Business Review, Vol. 73, pp. 59-67.

Mayer, S.J. and Russel, J.S. (1987), "Behavior modeling training in organizations: concerns and conclusions", Journal of Management, Vol. 1 No. 3, pp. 21-41.

Mayer, R.C. and Schoorman, F.D. (1998), "Differentiating antecedents of organizational commitment: a test of march and Simon's model”, Journal of Organizational Behavior, Vol. 19 No. 1, pp. 15-28.

McClough, A.C. and Rogelberg, S.G. (2003), "Selection in teams: an exploration of the teamwork knowledge, skills, and ability test", International Journal of Selection and Assessment, Vol. 11 No. 1, pp. 56-66.

McGregor, D. (1960), The Human Side of Enterprise, McGraw-Hill, New York, NY.

Morris, S. (2015), "Can continuous improvement continue indefinitely?", Lean Management Journal, Vol. 5 No. 9, pp. 9-11.

Morris, D.S. and Haigh, R.H. (1994), "How to Stop quality improvement teams from quitting", Total Quality Management, Vol. 5 No. 4, pp. 161-132.

Moye, M.J. and Henkin, A.B. (2006), "Exploring associations between employee empowerment and interpersonal trust in managers", Journal of Management Development, Vol. 25 No. 2, pp. 101-117.

Naveh, E., Marcus, A.A. and Moon, H.K. (2004), "Implementing ISO 9000: performance improvement by first or second movers", International Journal of Production Research, Vol. 42 No. 9, pp. 1843-1863.

Nwabuez, U. (2011), "Implementing TQM in healthcare: the critical leadership traits", Total Quality Management, Vol. 22 No. 3, pp. 331-343.

O'Neal, N. (2018), "Fighting the fear of change", Financial Planning, Vol. 48 No. 2, p. 56.

Oakland, J.S. (1995), Total Quality Management. Text with Cases, Butterworth Heinemann, Oxford.

Oliveira, M., Curado, C. and Henriques, P.L. (2019), "Knowledge sharing among scientists: a causal configuration analysis", Journal of Business Research, Vol. 101, pp. 777-782.

Panwar, A., Nepal, B., Jain, R. and Prakash Yadav, O. (2013), "Implementation of benchmarking concepts in Indian automobile industry - an empirical study", Benchmarking: An International Journal, Vol. 20 No. 6, pp. 777-804.

Pastore, R. (2003), “Why we fear knowledge management”, CIO, Vol. 17 No. 5, p. 14.

Prieto, M. (2015), "The other from an educational perspective: beyond fear, dependence", Studies in Philosophy and Education, Vol. 34 No. 3, pp. 297-309.

Psychogios, A.G., Wilkinson, A. and Szamosi, L.T. (2009), "Getting to the heart of the debate: TQM and middle manager autonomy", Total Quality Management, Vol. 20 No. 4, pp. $445-466$.

Randeniya, R., Baggaley, N. and Rahim, M.A. (1995), “Total quality management: the need to uncouple empowerment", Total Quality Management, Vol. 6 No. 3, pp. 215-220.

Repenning, N.P. (2000), "Drive out fear (unless you can drive it in): the role of agency and job security in process improvement”, Management Science, Vol. 46 No. 11, pp. 1385-1396.

Roberts, P. (2004), "A survey of TQM success factors in the UK", Total Quality Management and Business Excellence, Vol. 15 No. 8, pp. 1109-1117.

Robison, J. (2011), "Overcoming the fear of change", Gallup Management Journal Online, p. 1, (accessed 1 July 2011).
A review of problem of fear in TQM 
TQM 32,6
Sadikoglu, E. (2005), "Integration of work measurement and total quality management", Total Quality Management and Business Excellence, Vol. 16 No. 5, pp. 597-605.

Schullery, N.M. and Gibson, M.K. (2001), "Working in groups: identification and treatment of students' perceived weakness", Business Communication Quarterly, Vol. 64 No. 2, pp. 9-30.

Schulz, C.G. (2006), "Applying Sullivan's theory of anxiety versus fear", Psychiatry: Interpersonal and Biological Processes, Vol. 69 Nos 1/2, pp. 140-112.

Sethi, R. (2000), "New product quality and product development teams", Journal of Marketing, Vol. 64 No. 2, pp. 1-14.

Soltani, E., Lai, P.C. and Gharneh, N.S. (2005), "Breaking through barriers to TQM effectiveness: lack of commitment of upper-level management", Total Quality Management and Business Excellence, Vol. 16 Nos 8/9, pp. 1009-1021.

Stabler, J.D. (1995), “The eye of the storm”, Journal for Quality and Participation, Vol. 18 No. 4, p. 54.

Stoner, J.A.F., Freeman, R.E. and Gilbert, D.R. Jr (2001), Kierowanie, PWE, Warszawa.

Sălăgean, H.C. (2014), "Implementation of quality management - the importance of leadership styles", Managerial Challenges of the Contemporary Society, Vol. 7 No. 1, pp. 164-169.

Taher, N.B. and Krotov, V. (2016), "Business process reengineering: addressing sources of resistance and sabotage tactics", Journal of Competitiveness Studies, Vol. 24 No. 3, pp. 145-163.

Tamimi, N. and Gershon, M. (1995), "A tool for assessing industry TQM practice versus the Deming philosophy", Production and Inventory Management Journal, 1st Quarter, Vol. 36 No. 1, pp. 27-32.

The antidote to fear-driven management (2012), Executive leadership, Vol. 27 No. 3, p. 6.

Thor, L.M. (1993), "The human side of quality: employee care and empowerment", Editorial and Opinion, 21 pp Paper presented at the League for Innovation in the Community College's Conference, Community Colleges and Corporations: Partners in Total Quality Management, Irvine, CA, February 1.

Tremblay, M., Vandenberghe, Ch. and Doucet, O. (2013), "Relationships between leadercontingent and non-contingent reward and punishment behaviors and Subordinates' perceptions of justice and satisfaction, and evaluation of the moderating influence of trust propensity, pay level, and role ambiguity", Journal of Business and Psychology, Vol. 28 No. 13 , pp. 233-249.

Tsai, M.H. and Young, M.J. (2010), "Anger, fear, and escalation of commitment”, Cognition and Emotion, Vol. 24 No. 6, pp. 962-973.

Waller, M.A. and Ahire, S. (1996), "Management perception of the link between product quality and customers' view of product quality", International Journal of Operations and Production Management, Vol. 16 No. 9, pp. 23-33.

Ward, L. and Warner, M. (1996), Creating Environments for Change: Strategies for Transcending Fear, Paper presented at the annual meeting of the American College Personnel Association, Baltimore MD.

Weeks, W.A., Roberts, J., Chonko, L.B. and Jones, E. (2004), "Organizational readiness for change, individual fear of change, and sales manager performance: an empirical investigation”, Journal of Personal Selling and Sales Management, Vol. 24 No. 1, pp. 7-17.

Whitaker, D. (2009), "Collaboration: the only 'game' for team performance (cover story)", Training Journal, pp. 50-54.

Wicks, A.C. (2001), "The value dynamics of total quality management: ethics and the foundations of TQM", Business Ethics Quarterly, Vol. 11 No. 3, pp. 501-535.

Witt, L.A., Kacmar, K.M. and Andrews, M.C. (2001), "The interactive effects of procedural justice and exchange ideology on Superior-rated commitment", Journal of Organizational Behavior, Vol. 22 No. 5, pp. 505-516.

Youssef, M. (2010), “Taken task”, Quality Progress, Vol. 43 No. 6, p. 80. 
Zhao, C., Liu, Y. and Gao, Z. (2015), "An identification perspective of Servant leadership's effects", Academy of Management Annual Meeting Proceedings, Vol. 2015 No. 1, p. 1.

Zimbardo, P.G., Johnson, R.L. and McCann, V. (2017), Psychologia. Kluczowe koncepcje. Motywacja I Uczenie Sie, PWN, Warszawa.

Zink, J.K. (1995), Total Quality Management as a Holistic Management Concept, Springer, Berlin, New York.

\section{Further Reading}

Craswell, J.W. (2013), Projektowanie Badań Naukowych, Wyd, UJ, Kraków.

Davidson, G. (1995), "Quality circles didn’t die - they just keep improving”, CMA Magazine, Vol. 69 No. 1, pp. 6-7.

Easterby-Smith, M., Thorne, R. and Jackson, P.R. (2015), Management and Business Research, Sage, Los Angeles.

\section{Corresponding author}

Marek Bugdol can be contacted at: marek.bugdol@uj.edu.pl
A review of problem of fear in TQM

For instructions on how to order reprints of this article, please visit our website:

www.emeraldgrouppublishing.com/licensing/reprints.htm

Or contact us for further details: permissions@emeraldinsight.com 